\title{
The Role of Government in MSMEs:
}

\section{The Empowerment of MSMEs During the Free Trade Era in Indonesia ${ }^{1}$}

Dhian Kusumawardhani², Amy Y. Rahayu ${ }^{3}$ and Irfan Ridwan Maksum 4

\begin{abstract}
As the era of globalisation has progressed, the free-trade paradigm - in which the role of government in every aspect of economic development is minimised, replaced by the power of the free market has inevitably spread across countries throughout the world. Despite the positive outcomes that can be obtained from the idea of free liberalisation in achieving economic growth and opportunities, this paper will propose that governments must continue to have a strong role in their countries' economies, particularly in developing countries such as Indonesia. This argument is justified on the basis of the threat that free trade poses to some informal sectors called micro and small and medium enterprises (MSMEs), which have commonly shown low levels of competitiveness in the global market. Thus their very survival heavily depends on government involvement. The Indonesian government has launched many policies to help SMEs become and remain more competitive; for example, the Technology for Regions Program (Iptekda), which combines state support and a market-based approach for MSMEs' empowerment.

This paper conducts a case study of the Iptekda program for the empowerment of MSMEs in Malang Raya. The research will address two issues: why government intervention is still required for MSE capacity-building; and how the program may help MSMEs improve their capacity and competitiveness. To answer these questions, this paper will apply a qualitative approach that uses indepth interview with the owners of five MSMEs. The results reveal that MSMEs benefit from the program in terms of improved productivity, marketing and insights into MSMEs as an economic sector. The research limitation is that it consists solely of qualitative findings; the findings need to be combined with quantitative data for more-reliable results. Replication of this study using larger samples and a broader geographic base is suggested for promoting programs to empower MSMEs in Indonesia.
\end{abstract}

JEL Classification: M48, N55

Keywords: Role of Government, MSE, Indonesia, Free Trade Era

\footnotetext{
${ }^{1}$ The publication is part of dissertation research which title the Technology Diffusion Policy Implementation for Empowering Micro and Small Enterprises in West Java Sub District and Malang Raya East Java.

${ }^{2}$ University of Indonesia

${ }^{3}$ University of Indonesia

${ }^{4}$ University of Indonesia
} 


\section{Introduction}

The impact of globalisation has increasingly bound the world together and created different ways in shaping the map of the world. Globalisation emerged after World War II, and accelerated in the 1980s and 1990s. One of the different ways globalisation is manifested is in the minimisation of the government's role, particularly in economic development, and its replacement with the market system.

According to Low (2001), economic growth can be achieved by implementing policies that foster trade liberalisation, openness, and macroeconomic growth, which lead to the redistribution of income, wealth, and economic opportunities (Low 2001, p.3).Governments worldwide began to reduce policy barriers that they considered to have negative effects on international trade and investment (Kartasasmita 2000, p.3). Giddens (1999, p.15) argues that the globalisation process is not to be taken for granted. The effect of globalisation for many who live outside Europe and North America is similar to Westernisation - or perhaps Americanisation.

Developing countries' ambition to alleviate their poverty and achieve the same standard of living industrialised countries has resulted in the extension of development. One of the contributing factors to the development process is private-sector development and investment, in terms of providing private-sector efforts and investment that promote economic development to achieve economic growth and reduce poverty (World Bank 2005b, p.273 as cited in Wie 2006 p.2).

While developed countries give financial aid and technology inputs to modernise developing countries, these measures have social and economic costs. One of the unintended consequences is discrimination against domestic enterprises. In the Indonesian context, a survey of perceptions reported by Rinakit and Soesastro (2004) suggests that the domination of foreign enterprises as the result of liberalisation policies has weakened the role of micro and small enterprises in the national economy (Soesastro 2004, p.7). In addition, the liberalisation policies are not in accordance with the 1945 Indonesian Constitution. Article 33 mentions that:

“(1) The economy shall be organized as a common endeavour based upon the principles of the family system.

"(2) Sectors of production which are important for the country and affect the life of the people shall be under the powers of the State.”

Based on these two paragraphs in Article 33, it may be concluded that Indonesia should not apply liberalisation in its economy, as the sectors that are important to the country and affect the prosperity and life of the people must be under the power of the state. The enterprises that come under the article are MSMEs and cooperatives, since these entities are based on the 
kinship system, where the welfare of the group is more important than that of the individual (Sadoko 1995, p.1).

Furthermore, according to the World Bank Report (2006), MSMEs ${ }^{5}$ in developing countries constitute about $99.95 \%$ of total enterprises; this figure is the same for Indonesia. According to the data from Indonesia's Ministry of Cooperatives and Small and Medium Enterprise Ministry, MSMEs have provided significant job opportunities, employing as much as $90 \%$ of the country's workforce.

The ability of this sector to absorb labour, especially in rural areas, can indirectly reduce unemployment and increase the income of local communities (Tambunan 2009). Table 1 shows the employment contribution made by the micro and small enterprise sectors in comparison to medium and large enterprises in Indonesia.

Table 1: Enterprise-Level and Labor Absorption in 2010

\begin{tabular}{|l|l|r|r|r|}
\hline \multirow{2}{*}{ No. } & Type of Scale & $\begin{array}{r}\text { Number of } \\
\text { Units }\end{array}$ & Number of Workers & \% \\
\hline \multirow{2}{*}{1} & Micro units & $53,207,500$ & $93,014,75$ & 90.98 \\
\cline { 2 - 5 } & Small units & 573,601 & $3,627,16$ & 3.55 \\
\cline { 2 - 5 } & Medium units & 42,631 & $2,759,85$ & 2.70 \\
\hline 2 & Large Enterprises & 4,838 & $2,839,71$ & 2.78 \\
\hline
\end{tabular}

Source: Ministry of Cooperatives and SMEs 2011 (www.depkop.go.id)

Table 1 shows that the largest share of employment is in the micro-enterprises sector (90.98\%), followed by small enterprises (3.55\%); the remainder is in medium and large enterprises. This is in line with Berry (1998), who found that the amount of demand for workers in small enterprises with traditional technology is greater than in large entities that are already using high technology (Berry 1998 in Tambunan 2009, p. 1). As Warjiyo (2004,

\footnotetext{
${ }^{5}$ The definition of MSMEs in Indonesia varies. For example, Statistics Indonesia defines MSMEs as the enterprises that consist of micro, small and medium enterprises that can be differentiated based on the number of employees. The micro level have less than 10 employees, small enterprises have 6-10 employees and medium enterprises have 20-99 employees. The Law Number 20 Year 2008 article 8, defines MSMEs based on the assets they have. The micro enterprises have net assets that are less than IDR 50 million (land and buildings excluded) or less than IDR 300 million total annual sales. Small enterprises have net assets from IDR 50 million - IDR 500 million (land and buildings excluded), or IDR 2.5 billion total annual sales, medium enterprises have net assets ranging from IDR 500 million - IDR 10 billion (land and buildings excluded), or total annual sales from IDR 2.5 billion - IDR 50 billion. The focus in the research is on the micro and small enterprises with the combination of both definitions of assets and employees.
} 
p.1) asserts, the growth of MSMEs, particularly during the 1998 Asian financial crisis, has shown that MSMEs can be the best path to economic recovery for Indonesia.

MSMEs have been one of the major areas of concern to many policy makers in an attempt to the rate of growth in low income countries. Despite the contributing factors to MSMEs economic development, there are several concerns regarding their sustainability. The reason for this sustainability is that the old paradigm of economic growth at the New Order Era, which focused on large scale firms to accelerate the exports, has resulted in a lack of interest and effort in the expansion of MSMEs. As the result, capitals as well as the lack of infrastructure and human resources capacity building become several constraints for MSMEs.

Prasentyoko (2010) argues that although the number of MSMEs is quite big, their contribution to the Gross Domestic Product is only 55\%, and their export rate is only $27 \%$. Consequently, most domestic products in Indonesia still heavily rely on import. As data from the Indonesia Statistics Bureau (2010) noted, during 2009, China was the major source of imports to Indonesia, with an import value of US\$12,001 billion (Suyatna 2010, p.3).

As a consequence, the index of competitiveness during 2009-2010 has placed Indonesia at the low level of 54. The level is possibly better than those of Vietnam and the Philippines, but in no way allows Indonesia to compete successfully with Thailand, Malaysia, and Brunei (Prasentyoko 2010, p.16). Factors that contribute the low level of global competitiveness, particularly for MSMEs, include labourers' low productivity and skills and the low quality of their products.

According to Tambunan (2009), technology can elevate the level of MSMEs' productivity (p.6). The use of manual equipment (with a low level of mechanisation) and the lack of managerial skills affect their productivity and competitiveness. Moreover, the Dhaka Chamber of Commerce and Industry (DCCI) further stated that the success of MSMEs in an era of globalisation is largely determined by their ability to acquire, integrate and implement technology in their overall business strategy (DCCI 2003, p.5).

One alternative solution for the problem is to improve MSMEs production processes through enhancing their use of technology and management practices (UNCTAD 2005, p.10). The government of Indonesia consequently implemented a technology-diffusion program after the economic crisis in 1998. Under the Technology for Regions Program (Iptekda), three government research institutes originally aimed to give financial and technology assistance to MSMEs in some provinces in Indonesia (Brojonegoro 2006). However, since 2001, only the Indonesia Institute of Sciences (LIPI) still remains to implement the program.

The scheme of the program has been improved since the involvement of a number of public universities' research centres. In addition, the scheme of technology and capital assistance attempts to combine market-based and state-based approaches. In this scheme, the government - represented by LIPI and the universities - provides machinery and equipment and the mechanisms for empowering MSMEs', while the MSMEs' are responsible for the 
sustainability of their own empowerment, largely in the form of the management of financial credit by informal institutions established on behalf of the MSMEs” interests.

This paper will highlight the role of the government in MSMEs' empowerment in terms of technology usage and capital assistance through the Technology Region Program (Iptekda) in Malang Raya. The research will address two issues: first, why government intervention is still required for MSE capacity-building; and second, how the program may help MSMEs improve their capacity and competitiveness.

To answer these questions, the paper will highlight Indonesia's state policy on technology for MSMEs' based on a market-based approach in Indonesia, particularly before and after the Asian economic crisis in 1998. Furthermore, this paper will apply a qualitative approach by using in-depth interviews with five owners of food-industry MSMEs' participating in the Iptekda program.

The decision to use a case-study approach is due to two reasons. First, Iptekda as an MSMEpromotion program combines state- and market-based approaches to empower MSMEs in Malang Raya. Second, the Malang Raya MSMEs experience in implementing the technology-diffusion program through Iptekda highlights the role of technology for MSMEs in improving their capacity, as well as their productivity to increase competitiveness in the global market.

\section{Literature Review}

This section will examine some of the literature related to MSMEs' empowerment from a state-based to a market-based approach. The analysis will highlight some paradigms in public policy focusing on MSMEs' problems in enhancing their capacity and productivity, which require public policies to address them. Furthermore, public-policy paradigms may reveal the relationship between the state and citizens in achieving national goals for economic growth. Therefore, this section will address the evolution of the state-based and market-based approaches in empowering MSMEs in Indonesia.

\section{A. Policy for MSME Empowerment before the Economic Crisis of 1998.}

The New Order era under Suharto's leadership had strongly supported MSMEs' empowerment through capital subsidies and technical assistance. According to the USAID Partnership for Economic Growth Project report in 2000, the New Order Era tended to apply the old paradigm of public administration, in which the state becomes the central agency to provide services for MSMEs. As a result, many policies were focused on subsidies that assisted uncompetitive and inefficient enterprises (Bhasin \& Venkataramany 2010, p.98).

The old tradition of public administration was an approach adopted from Keynesian economics, which upholds government intervention in economic activity. This state intervention was necessary to moderate cycles of economic activity. It also aimed to mitigate the adverse effects of a free market, especially toward marginal sectors of the society. 
Through proper economic policy the government can help its marginal citizens to increase their standard of living.

Wie (2006, p.30) found that attempts to empower MSMEs based on the traditional paradigm of public administration has resulted in direct assistance programs. For example, the government has provided a subsidy for credit programs, called "small-enterprises credit" (KUK), and training programs in the form of the Small Industries Development Program, or "Program Pembinaan dan Pengembangan Industri Kecil (BIPIK)".

However, most of the program has been considered ineffective and inefficient. As Tambunan (2011) asserts, the government has supported many government-sponsored MSMEs through its credit scheme, but the most MSMEs did not receive the aid because they were located in rural areas. As a result, MSMEs "financing daily business operation rely on their own savings, money from relatives, and credit from informal lenders” (Tambunan 2011, p. 71).

In addition, the technical assistance that the government has provided through BIPIK programs has not been successful in improving the productivity, technical capabilities or growth of MSMEs. This is largely because the clusters of enterprises that had received support from the Ministry of Industry did not maintain the facilities built with the support, which then deteriorated (PPTA and the Asia Foundation 2005, p.35 as cited in Wie 2006, pp.32-33).

Moreover, to improve MSMEs' competitiveness, in 1992 the government implemented the Foster Father Program, aimed at building strong collaboration between large and small enterprises. The government assigned large enterprises to assist small enterprises in terms of capital, technology and sharing their revenues for MSMEs' empowerment. Nevertheless, the program has been considered a failure, since there are indications that the large enterprises only exploited small enterprises in terms of market monopoly, providing materials, and setting product prices (Widyaningrum et al., 2003, pp. xiii-xiv).

Based on these examples, it can be concluded that the traditional paradigm of public administration has influenced the policy approach towards MSMEs in Indonesia. MSMEs have been viewed as an informal and economically weak sector (golongan ekonomi lemah) that has required government assistance based on welfare or equity considerations, and has needed the government's protection from competition (Hill 1997, p.266, as cited in Wie 2006, pp.27-28). Furthermore, Wie (2006, p. 33) added that two factors have contributed to the failure of MSME development policy. First, the services provided by the government agencies did not meet the needs of MSMEs. Second, there have been inefficiencies and a lack of coordination between the various agencies administering credit assistance to MSMEs' owners.

The condition has worsened since the problem of corruption has made MSE owners the victims of administrative and bureaucratic processes as they have sought to legalise their businesses. Some have felt compelled to make illegal payments for the services they receive from government institutions (Olawale \& Garwe, 2010, as cited in Irjayanti \& Mulyono 
2012). Due to some weaknesses in the government intervention program for MSMEs, after the Asian economic crisis in 1998 and the influence of the Structural Adjustment Program proposed by the International Monetary Fund (IMF), the Indonesian government reformed the MSE-empowerment policy to take a market-based approach. The next section will provide the implications of this approach for the policy.

\section{B. The MSE Empowerment Policy after the Economic Crisis of 1998.}

The 1998 Asian economic crisis offered some lessons for MSMEs. First, the government's view towards MSMEs' role in the economy has changed since they were shown to be the most successful sector in surviving the crisis. Second, the empowerment of MSMEs has shifted to a market-based approach that focuses on efficiency rather than the welfare of the individual MSE owners and employees. The shift cannot be separated from the influence of the Structural Adjustment Program (SAP) from the International Monetary Fund (IMF) and the World Bank, which requested the governments of developing countries to reform their financial and bureaucratic sectors (Kurniawan 2006; Wie 2006).

The SAP, under the supervision of the IMF and the World Bank, attempts to implement a neoliberal paradigm of economic development in developing countries; this has minimised the role of the state in providing services and let the private sector promote economic development. In terms of public policy, the SAP was in line with the public choice theory, which argues that the government and the market are parallel organisations that share their functions, on the assumption that the government, with its diverse responsibilities and functions, cannot possibly provide the best service or goods for its citizens.

To improve how the government provides public service, therefore, government should let markets to fill the demand from citizens. To provide better public service, the market-based approach argues that the bureaucracy's undesirable monopoly can only be solved by letting the market provide the public service. Bureaucrats normally use their power to guard all information for their own personal interest and financial gain.

In addition, the bureaucrats' monopoly on providing services limits the services that an individual can choose. Citizens have no way to compare alternative services. The market, on the other hand, can possibly create competition in providing services, which eventually can improve the government services. If the market or competitive institutions are allowed to determine policy decisions, therefore, this can create a better society (Guys, 2001).

The government intervention, however, has led to the increasing number of government agencies and constitutional authorities, which has resulted in control and coordination problems (Beresford 2000, pp.55). Advocates of the market model, therefore, have concluded that the way to create a better government is by introducing neoclassical economic policies that focus on reducing the size of government, by exercising budgetary self-control, downsizing, privatisation and deregulation (Wilenski 1986; Self 1993; and Davis 1997, as cited in Goldspink 2003). Friedman (1960) claimed that the most efficient distributor of 
resources is a free market, which allows the forces of supply and demand for goods and selfinterest to respond efficiently (Friedman 1960, as cited in Beresford 2000, p. 59).

In accordance with the market-based approach, MSMEs are not viewed as either a weak sector or a social group. As a consequence, Brojonegoro (2011) asserts that the policies to improve MSMEs' capacity and productivity after the crisis can be divided into three categories. The first is public policies that aimed to open business prospects, eliminate discrimination, and push for the formalisation of MSMEs. The second is public policies in which the goal is to strengthen specialisation and establish partnerships between small and large enterprises. The third is a group of public policies in which the objective is to empower a select group of MSMEs to minimise the possibility of distortions in resource allocation. These policies contain two important requirements. The first is the improvement of the investment climate; the second is the elimination of discrimination against MSMEs due to market mechanisms (Bojonegoro 2011, p. 34).

These three categories are in line with Law No. 20/2008 regarding Small and Medium Enterprises (SMEs). The law focuses on three policy directions: providing open access to market development through licensing and registration and intellectual property rights; investing public goods and building institutional capacity by limited long-term subsidies from the Business Development Service (BDS); and reducing traditional public intervention by eliminating the subsidised credit scheme.

The market-based approach, which focuses on efficiency rather than welfare, has not increased the competitiveness of MSMEs. This is because the Act does not make a distinction between micro, small, and medium enterprises in developing their capacity. Practically, these enterprises have different needs, and thus require different empowerment approaches. Moreover, Launa and Fajar (2010, p.8) suggest that the free-market mechanism addressing the issue of efficiency and limited traditional public intervention was actually not targeted at poor or marginalised enterprises such as MSMEs. Instead, the market-based approach is designed to guarantee that the "cake of welfare" has been distributed evenly among the elites and interest groups.

For example, based on Law Number 20/2008, article 20 mentioned that the government will motivate the SMEs to get a certificate of intellectual property rights (IPRs). The empirical study by Sinaga (2013) mentioned that only about 7.2\% of MSMEs recognise intellectual property rights (IPRs). The lack of MSMEs' skills and awareness about the use of technology to improve their productivity may become a constraint to the implementation of IPRs. In other words, the law does not represent what the reality and current condition of MSMEs actually is.

In addition, the research Center of SMERU ${ }^{6}$ has revealed that the process of licensing is the most difficult for MSMEs. This is because business licenses for location (SITU) require an assessment from the government that the enterprise complies with a spatial plan. The rules

${ }^{6}$ SMERU is the name of one research center in Indonesia 
and process to obtain a SITU vary from one province to another, and the process is complicated and costly. The license needs to be renewed every year (Mouragane 2012, p. 13).

Despite criticism of the market-based approach to policies for MSE promotion, the findings from a recent study that SMEs engaging MSMEs as subcontractors to large assembling firms has proven more effective in developing viable MSMEs, including improving their technology capabilities, than the old paradigm of protective programs (Hayashi 2002, as cited in Wie 2006, p. 36). The empirical findings suggest that the market-based approach should identify and differentiate micro, small and medium enterprises in terms of scale and sector.

This is in line with Prasentyoko (2010, p. 41) who proposes that for micro and small enterprises the empowerment policy should be based on social enterprise within a [?] business model. In this model, the role of government as the empowerment agency is still required and important, because the in the paradigm of social enterprises, the MSE is viewed as a part of solving social problems. In contrast, the market-based approach may suit medium enterprises, particularly those in the manufacturing and craft sectors, which contributed 6.28\% of GDP in 2002-2006.

Analysis suggests that one approach cannot fit all enterprises or circumstances. The need to identify the class, needs, and culture of MSMEs must be acknowledged to improve MSMEs' competitiveness. Competitiveness should not be directed by international donors, but should be relevant to the characteristics of MSMEs in Indonesia.

\section{The Combination of State-and Market-Based Approaches in Technology-Diffusion Programs for MSMEs'Empowerment}

As mentioned in the previous sections, both approaches to policy for MSE promotion in Indonesia have many strengths and weaknesses. In the state-based approach, although the government has applied a welfare approach to MSMEs' empowerment, it has classified MSMEs based on their scale. This can be seen from Law No. 9/2005, specifically designated the Law of Small Scale. This means the government has acknowledged that the policy applicable to MSMEs must differ from policies for medium or large enterprises. [not exactly sure if I understood this paragraph]

In a market-based approach, the strong push for efficiency has motivated MSE owners to become more entrepreneurial, entering more markets and cooperating more with large enterprises, particularly those in the manufacturing and creative economy sectors. However, from the point of view of other sectors, such as food enterprises, the market-based approach tends to use a one-size-fits-all strategy. As a consequence some of the policies may not suit with needs of MSMEs.

Although Indonesia has much experience in providing technology for MSMEs' capacitybuilding, most of the technology aids do not meet MSMEs' actual needs (Angkasa 2008). This is due to the fact that MSMEs and science and technology (S \& T) actors have different 
orientations. Brojonegoro (2010) agrees that the orientation of MSMEs is making profit for their business. However, to accelerate their revenues and improve their products, they need technology created by the S \& T sector.

To establish a win-win solution, the government has implemented the Technology for Regions Program (Iptekda) to address the issue of technology mastery for MSMEs to achieve competitiveness, particularly in the free-trade era. Partnership between government research institutions and MSMEs will bring mutual benefit for both parties if the products of the research match MSMEs' needs and bring economic value to the achievement of the national goals. The government, therefore, has implemented the program since 1998 by inviting many public institutions and academics to apply appropriate technology to enhance MSMEs' productivity.

The Technology for Regions Program is an example of a partnership that combines state- and market-based approaches, since the mechanism to empower MSMEs is through technology diffusion that is fully funded by the government, yet avoids the dependency of MSMEs on government aids. In other words, to be funded by the government, MSMEs and researchers of $S$ \& $T$ public institutes and universities should involve MSMEs' owners in formulating funding proposals.

The goal of the partnership is to assure that the technology proposed by the S \& $\mathrm{T}$ institutes meet the needs of MSMEs. On the other hand, the MSMEs are aware that the technology and capital assistance from the research institutes are not grants, but soft loans that should be paid periodically to local institutions. The local institutions will managed and revolve the funding in the interests of MSMEs in improving their capacity after the program has terminated their funding. Diagram 1 shows the mechanism of the Technology for Regions (Iptekda) program in detail. 


\section{Diagram 1. The Mechanism of Iptekda}

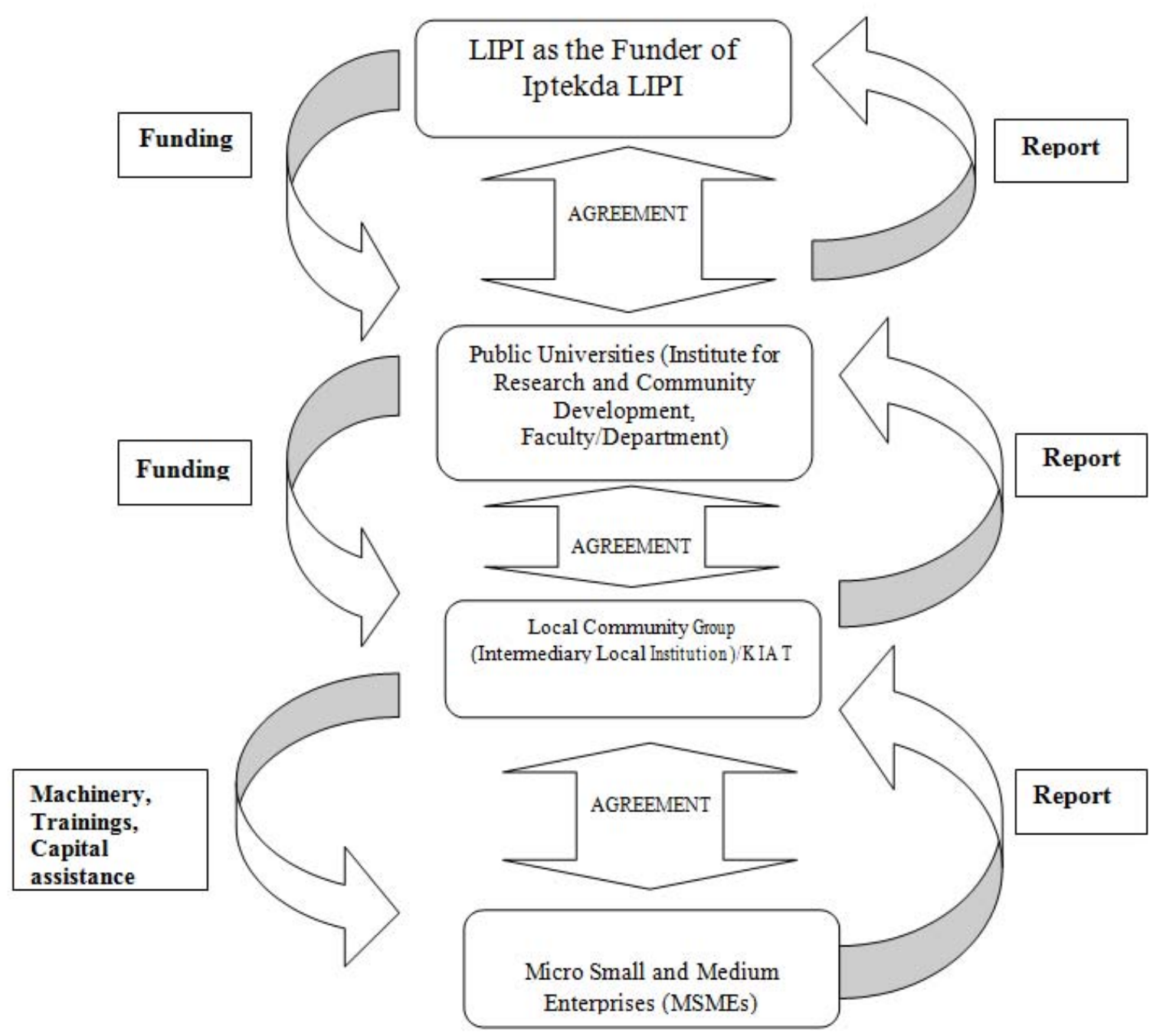

Diagram 1suggests that Technology for Regions (Iptekda) is in line with social entrepreneurship, where MSMEs are a sector requiring government intervention to protect them from the discrimination they may suffer in solely market-based policy environment. In addition, it also suggests MSMEs as key players in the national economy, with the capacity and ability not only to survive but also to grow independently after emerging from the capacity-building stage. The partnership between the government and MSMEs in the program shows that no single approach may work alone in improving MSMEs' competitiveness. 


\section{Methodology}

This study used the paradigm of interpretivist research in a qualitative approach. It is descriptive research focused on the role of the government in MSMEs in the City of Malang, East Java, Indonesia.

The study found study participants through purposive sampling of MSE owners. It focused particularly on MSMEs in the target group for Iptekda LIPI from 2000-2011 in the City of Malang, East Java Province. The main indicators for selection were the reliability and trustworthiness of the participants. In conducting the Iptekda LIPI program, most MSMEs have been under the supervision of the Institute for Research and Community Service, Agriculture Technology, at Brawijaya ${ }^{7}$ University.

After communicating with researchers from the Department of Agricultural Product Technology at the University of Brawijaya, it was noted that the MSMEs that could participate in the research were mostly from the food-product sector, producing items such as waluh (pumpkin) crackers, cassava, and snacks made from apple, as well as traditional herbs. Table 2 provides the profile of informants in the research.

Table 2 Profile of Food-Product MSMEs in Malang Raya that Participated in the Current Study

\begin{tabular}{|l|c|c|}
\hline \multicolumn{1}{|c|}{ Name of Enterprises } & $\begin{array}{c}\text { Number of Employment } \\
\text { (Employees) }\end{array}$ & Turnover Rate (IDR) \\
\hline UD R.Rovit & 8 & 2 million \\
\hline UD Dua Merpati & $15-20$ & 25 million \\
\hline UD Hidayah & 35 & 13 million \\
\hline UD Bagus & 25 & 10 million \\
\hline UD Sona Jaya & 40 & 35 million \\
\hline
\end{tabular}

The study used adjusted data-collection techniques as follows:

a. Face-to-face interviews and direct questioning of the participants.

b. Visits to each research site and documenting the activities to obtain deeper knowledge of the problem being investigated.

c. Review of various documents related to the research problem.

Data-analysis techniques included (a) data reduction; (b) the presentation of data; and (c) formulation and verification of conclusions.

\footnotetext{
${ }^{7}$ The Department of Agricultural Product Technology University of Brawijaya has participated in Iptekda LIPI since 2000
} 


\section{Discussion/Findings}

MSMEs are the main target group projected to receive the benefits of the Technology for Regions Program (Iptedka), especially in terms of improving the quality and quantity of production and providing new jobs. Based on the data collected, it was revealed that 16 MSMEs in Malang Raya joined the program between 2000 and2011; however, the researcher could only interview five food-industry MSE owners who had participated the program between 2005 and 2011; in part, this is because some of the MSMEs have collapsed, and others have ceased production after the owners passed away. However, another reason is the program's failure to change the mindset of the MSMEs owners, who were accustomed to receiving government grants rather than soft loans, as in the Technology for Regions Program. As a consequence, the program has proven to be unsustainable, since there is no financial guarantee for MSMEs to survive after their participation in the program has finished.

Secondary data from the database of the Secretariat of Iptekda LIPI reveals that the participant MSMEs have the same characteristics as the overall population of MSMEs: they still use traditional technology in their production processes; they have no financial reports that might compare their omzet rate and capital; they have fewer than 20 workers and sales revenue less than IDR 5,000,000 (5 million rupiahs); and they tend to work in small and simple production rooms with no knowledge of production-process hygiene. These characteristics mean that they cannot compete with medium or large enterprises in terms of production capacity, marketing networks, or product innovation. Acknowledging their limitations, a researcher from the Institute of Research and Community Development at Brawijaya University has invited MSMEs to join the Technology for Regions (Iptekda) Program. One interesting point is that most of the participants reported being aware of the need of technology for their production processes, but that they did not know where to find the information. As a result, when Brawijaya University invited them to join the Iptekda program, they were enthusiastic:

"I was looking for a program that may cope with my needs as a businessman. I asked for Industry and Trade Service at the regions (Disperindag) but they said they do not have that kind of program. Then, I met a Brawijaya researcher who came to my house and invited me to join the program. I said yes. Even though there is a soft-loan mechanism for every piece of machinery I get, the criteria are not difficult and I do not mind if I have to pay the soft loans for the technology that I received, since it is very useful for my business growth.” (Interview, UD Merpati owner, Batu, 13 July 2013)

"I was helped by Brawijaya University for two years starting in 1990. The university regularly sent a student to work as an apprentice in my enterprise. After I encountered a problem with production, a Brawijaya security officer introduced me to a team of researchers who assisted MSMEs with machinery. They invited me into the program, which mainly gives technology assistance and capital, although I have to repay this assistance. I was 
reluctant to accept at first, but when I found that the money that I paid would improve my business matters, I agreed. Now I have completely repaid the loan. The bank now trusts me based on my performance in the program, which has made it easier to get loans from them.” (Interview with UD Hidayah owner, Batu, 10 July, 2013).

The need for technology intervention from public universities and research institutes shows that the collaboration and cooperatives between government represented by Brawijaya University and LIPI very effectively accelerates the capabilities of MSMEs as the target group. The cooperation is also in line with the Presidential Decree No. 20/2005, Article 15, which states that every non-commercial research output should be used to assist MSMEs' capabilities.

In this program, the researcher assisted participating MSMEs with capital, machinery and equipment, training, and infrastructure renovation to meet the Good Manufacturing Processes standard. After three years, interviews with the participants revealed that the program successfully delivers a science- and technology-based approach for MSMEs' production process. In addition, the program also speeds up production time, reduces production costs, and increases business revenues. In regards to these benefits, the following sections will explore why government intervention is required and how the program may improve MSMEs' competitiveness based on the findings in the local area examined in this study.

\section{A. Creating Science-Based MSMEs}

Science-based MSMEs are one of the targets in Indonesia's Long-Term National Plan (RPJP) 2005-2025, which is regulated under Law No. 17/2005. According to the policy, improving MSMEs' competitiveness by creating science-based MSMEs is a national goal; this goal can be attained by improving their capacity and knowledge of the technology involved in every product they produce. The Technology for Regions (Iptekda) Program is one of the alternatives for achieving these improvements.

Interviews with the Technology for Regions (Iptekda) participants in Malang Raya revealed that their business operations have changed substantially since they have adopted technology innovation and obtained mentoring from local research institutions, including LIPI. Some employers feel that although they receive new machinery to accelerate the production process, the owner does not reduce the number of employees.

“The machinery that has been given in the program is very beneficial for increasing our productivity. We used to produce $10 \%$ of ginger crackers before the program, now we can increase almost $20 \%$ of the crackers. In addition, the time of production can be sped up because of the machine usage. The number employees has also increased because we need additional people to do jobs related to packaging and marketing." (Interview with UD Sonajaya $^{8}$ owner, Batu 15 July 2013)

\footnotetext{
${ }^{8}$ UD Sonajaya is one of food MSEs that produces ginger crackers (emping jahe). They had 5 female employees
} 
Moreover, the Technology for Regions Program (Iptekda) provides an alternative solution for improving financial capacity, since the period of payment is not burdensome. According to the recipients, when they have some additional household needs, KIAT (the local organisation that manages the fund) can give additional time for the MSMEs owners to make payments. The strategy is used by the researchers from Brawijaya University for maintaining a relationship with the MSMEs owners and the continuity of technology usage after their participation in the program finishes.

An informant from KIAT said, "As the mechanism of the program is quite new for recipients used to thinking that every government fund and facilitation is a grant, we have to ensure that [they understand that] the funding for every piece of machinery they receive must be treated as a soft loan. However, we should understand that we have to be flexible about repayment.” (Interview with KIAT member, August 5 2013).

Nevertheless, there have also been some problems related to the costs associated with the technology adopted. For example, although the machinery has been proven effective in increasing MSMEs' productivity, the cost of electricity can also be higher. One informant said, "The electricity has increased because it follows the capacity of production. However, our production and sales are still able to keep up with the increasing cost of electricity." (Interview with owner of UD Dua Merpati, Batu, 13 July 2014).

This information shows that the collaboration between public universities and public research institutions as government representatives is necessary for MSE owners to reach competitiveness goals. However, such technology interventions are only a bridge for MSMEs to reach competitiveness. The local government must also provide non-technological support, including regulations to protect the MSMEs, especially in terms of opening the market network for them. For example, the local government may regulate that every restaurant must use products from UD Hidayah for one or two of their recipes.

\section{B. Improving Quality of Human Resources in Marketing Management}

Their participation in Iptekda LIPI gives the MSMEs additional knowledge about sales and marketing. This is because the program researchers mentor the MSMEs owners in managerial skills such as performing simple accounting for their production and sales notes. In addition, MSMEs are also trained to keep a log book for every cycle of their production process. According to one of the informants,

"I did not know how to note my expenses for every production process. I often forgot to do that. But Mrs A from Brawijaya taught me to do simple accounting. As a result, now I know how much my net revenues are and how much production I have achieved in one

before joining the program and got sealers, ginger washing machine, roaster from Iptekda. These machines have been improving their productivity and reducing the time of production. For example, before the ginger washing machine was introduced in their production, they had to spend 1 hour per day washing the ginger. After using the machine, they only needed 20 minutes. 
day. In addition, she closely monitored me to ensure I kept the production log book. This is new for me and I have been thankful to Mrs A for teaching me that new information. Now, I am confident to share my knowledge to my GRASS"9. (Interview with owner of UD Rasa Prima, 20 July 2013, Batu City).

The interviews conducted for this study suggest that every technology diffusion can improve MSMEs' knowledge, and that this knowledge can be shared with the other businesses in their community. As their knowledge improves, it will lead improvements in their marketing strategy in adjusting to market demand. One informant admitted,

"All these years, I did not know that my crackers should meet some standards of frying. I just fried them in traditional ways, which meant that the products did not have the same texture and form in every production. Sometimes we got complaints from our customers who wanted all the crackers to have the same frying procedure and taste. Now that we use our automatic roaster, we have no need to worry about customers' complaints.” (Interview with UD Yuan Kartika owner, 19 July 2013, Batu City).

With improvements in product quality, MSE owners also become motivated to innovate with their products. For example, UD Hidayah ${ }^{10}$ introduced two brands that serve different markets: RB, marketed in other districts of East Java, and Hidayah, marketed in Malang Raya. Furthermore, most MSMEs participating in the program reported that their revenues from sales have increased. For example, UD Hidayah has raised turnover from IDR. 750,000 monthly to IDR 8,5 million monthly and has increased the company's workforce to 36 persons.

Another MSE, UD Dua Merpati, has successfully penetrated into the export market, selling 30-40 tons of potato chips to Taiwan annually. The owner considers the loan scheme to be an investment in his business, as the new machinery helps him improve product quality and hygiene.

Regarding the role of the Government, most of MSMEs in Malang admitted that the government does not assist them with marketing issues. One informant said,

“The local government does nothing, while we hope that they may help us [not only] in terms of providing exhibitions. Although we appreciate their program of exhibitions,

\footnotetext{
${ }^{9}$ UD Sonajaya is a food MSE that produces ginger crackers (emping jahe). They had five female employees before receiving sealers, a ginger washing machine, and a roaster from the Technology for Regions (Iptekda) Program. These machines have been improving their productivity and reducing production time. For example, before the ginger washing machine was introduced, they had to spend one hour per day to wash the ginger. The machine only requires 20 minutes.

${ }^{10}$ UD Hidayah is one of seasoning home-industry that has been operated since 1990. At the beginning of the business operation, the enterprise only have 5 employees now the number has grown into 36 people and the management has been run by the daughter of the owner.
} 
sometimes they also burden us with the exhibition costs, making us think twice about cooperating with them.” (Interview with UD Sonajaya owner, Batu, 15 July 2013).

These field findings illustrate that the MSMEs expected more local government assistance in entering the market. The Technology for Regions Program (Iptekda) will not be useful in improving their capabilities if the government does nothing to support marketing efforts. The experience of UD Merpati in entering the export market shows the potential of MSMEs to improve their unit scales. As with UD Merpati, which started its business on the MSE scale with only five employees, once they reach export market, their business scale can be upgraded.

\section{Conclusion}

The case study of the Technology for Regions Program (Iptekda) for MSMEs' empowerment illustrates a state- and market-based mechanism to improve MSMEs competitiveness in an era of free trade. In this case, the program attempts to combine the state's roles, represented by public universities such as the Institute of Research and Community Development at Brawijaya University and LIPI, with private-sector cooperation, represented by MSMEs. The mechanism of the program includes public subsidies for soft loans to support technology, marketing, and other improvements in business capacity. The combination of these approaches has proven successful in creating science-based MSMEs, increasing productivity and improving human-resources management and marketing.

Nevertheless, the Technology for Regions Program will not be beneficial in the long term if the central or local governments still think sectorally. In other words, the solution of supporting the competitiveness of MSMEs through technology will not work if the government does not think globally and act locally.

To cope with this issue, several suggestions need to be considered. First, local governments should recognise the existence of MSMEs as the backbone of the national economy, and therefore give them high priority in every local development plan. For example, as a postprogram of Technology for Regions, the local government should open domestic and international market access to MSMEs' products; include their products in a government program $^{11}$ at schools or other businesses; channel their products to international trade with the help of government subsidies; and cut the red tape of bureaucracy associated with every regulation with which MSMEs must comply.

Second, at the national level, the government of Indonesia should revise Law No. 20/2008 and Presidential Decree No.17/2013, which have caused misinterpretation in generalising MSMEs' needs at the operational level. The case of Intellectual Property Rights for MSMEs shows that the government should not generalise the needs of MSMEs in order to meet competitiveness goals. This is because the MSMEs' existence, as well as their contribution to employment absorption, are already regulated in the Indonesian Constitution, in Article 33.

\footnotetext{
${ }^{11}$ For example, the milk for school program or wearing national clothes such as batik programs.
} 
According to Dernhardt and Dernhardt (2000), the government needs to resolve issues of justice, equity, participation, and leadership as major concerns. Applying a bottom-up approach to empowering MSMEs to fulfil MSMEs' needs is one solution.

\section{Acknowledgements}

The authors wish to thank Endang Sukara and Rochadi Abdulhadi from the Indonesian Institute of Sciences (LIPI) for their valuable input into this research.

\section{References}

Angkasa, W.I and Kasman, B.R. [2003] Pengkajian Mekanisme Difusi Teknologi Tepat Guna Pertanian. Prosiding Seminar Teknologi untuk Negeri, vol. V, hal. 140 - 155 /HUMASBPPT/ANY.

Asian Development Bank. 2004. Special Theme: The changing face of the microfinance industry, Annual Report 2004, http://www.adb.org/documents/reports/annual_report/2004/special- theme.pdf.

Beresford, Q. 2000. Governments, Markets and Globalization: Public policy in context, Allen \& Unwin, Crows Nest, NSW.

Bhasin, B.B and Venkataramany, A. 2010. Globalization of Enterpreneurship: Policy Consideration for SME Development in Indonesia. International Business and Economics Research Journal, vol. 9, no. 4, April. Online accessed [1 October 2014]. URL:

http://digitalcommons.sacredheart.edu/cgi/viewcontent.cgi?article=1029\&context=wcob _fac.

Brojonegoro, A. and Darwin, [initial?] (Eds.) 2006. Pemberdayaan UKM Melalui Program Iptekda LIPI (Empowerment of SMEs Through LIPI's Iptekda Program), LIPI Press, Jakarta.

Brojonegoro, A. 2010. Production Capacity Development of SMEs Through Infrastructure Develpment, R \& D and HRD: The Indonesian Perspective. Proceedings. APECATCWG Agricultural Technical Cooperation Working Group. Online accessed [20 November 2013]. URL: publications.apec.org/publication-detail.php?pub_id=1119.

Denhardt, R.B. and Denhardt, J.V. 2000. The New Public Service: Serving Rather than

Steering. Public Administration Review, vol. 60, issue 6. http://dx.doi.org/10.1111/0033$\underline{3352.00117}$

Dhaka Chamber of Commerce and Industry (DCCI) 2003. Assessing Appropriate Technology for SMEs. Economic Policy Paper. Online accessed [January 2013]. URL: http://www.dhakachamber.com/economic_policy/Appropriatetechnology.pdf.

Giddens, A. 1999. Runaway World: How Globalisation Is Reshaping Our Lives. Profile Books, Ltd., London. 
Goldspink, C. 2003. Rethinking Educational Reform - A Better Approach to Educational Improvement. Learning to Learn Project, Government of South Australia, Adelaide.

Guy, B.P. 2001. The Future of Governing (2nd ed.). University Press of Kansas, Lawrence, KS.

Irjayanti, M. and Aziz, A.M. 2012. Success Factors of Fast Moving Goods of Small Medium Enterprises in Indonesia. Journal of Global Enterpreneurship, vol. 4, no. 1. Online accessed [15 October 2014]. URL: http://www.globalresearch.com.my/journal/entrepreneurship v04n01/JoGE_January2013_V4N1.pdf\#page $=21$.

Kartasasmita, G. 2000. Globalisation and the Economic Crisis: The Indonesian Story. Lecture Note at the FASID/GSAPS/WIAPS Joint ADMP, Waseda University, October 26, 2000. p.3. Online accessed [20 November 2002]. URL: http://www.wcfia.harvard.edu.au/pdf.

Kurniawan, T. 2007. Pergeseran Administrasi Publik: Dari Perilaku Model Klasik dan NPM Ke Good Governance. Jurnal Ilmu Administrasi Negara, Vol.7, Januari.

Fajar,A dan Launa,PR. 2010. “UMKM dalam Pilar Kemandirian Bangsa.” Jurnal Sosial Demokrasi, Volume 9 Nomor 3. Juli-September. Jakarta, Pergerakan Indonesia dan Komite Persiapan Yayasan Indonesia Kita Online accessed [June 2014]. URL: http://library.fes.de/pdf- files/bueros/indonesien/07003/2010-09.pdf.

Low, L. 2001. Globalisation and Poverty Reduction: Can the Rural Poor Benefit from Globalisation?: An Asian Perspective. Paper for Expert Group Meeting on Globalisation and Poverty Reduction: Can the Rural Poor Benefit from Globalisation? Division for Social Policy and Development, United Nations, 8-9 November 2001, New York, p.3.

Prasentyoko, A. 2010. "Pemberdayaan UMKM sebagai Perwujudan Demokrasi Ekonomi di

Indonesia.” Jurnal Sosial Demokrasi Vol.9. Juli-September. Online accessed [June 2014]. URL: http://library.fes.de/pdf-files/bueros/indonesien/07003/2010-09.pdf.

Sadoko, I., Maspiyati, [initial?] et al. 1995. Pengembangan Uasaha Kecil: Pemihakan Setengah Hati. Yayasan Akatiga Bandung, Juni.

Sinaga, S. 2012. Utilisation of Intellectual Property Rights by Indonesian Small and Medium Enterprises: A Case Study of Challenges Facing the Batik and Jamu Industries. Thesis. Online accessed [30 September 2013]. URL: ro.uow.edu.au/cgi/viewcontent.cgi?article= 4522\&context=theses.

Soesastro, H. 2004. The Economic Crisis in Indonesia: Lessons and Challenges for Governance and Sustainable Development. Online paper. Online accessed [4 October 2014]. URL: http://www.pacific.net.id/pakar/hadisusastro/economic.html.

Suyatna, H. 2010. Revitalisasi Reorientasi Kebijakan UMKM Di Era Asia China Free Trade.

Social and Politics Journal, vol. 13, no. 3. Online accessed [3 September 2014]. URL : http://jurnalsospol.fisipol.ugm.ac.id/index.php/jsp/article/view/81. 
Tambunan, H.T.T. 2009. SMEs in Developing Countries. Palgrave MacMillan, New York. http://dx.doi.org/10.1057/9780230250949

Tambunan, T. 2011. Development of small and medium enterprises in a developing country: The Indonesian case." Journal of Enterprising Communities: People and Places in the Global Economy 5.1. Online accessed [29 September 29, 2014]. URL: www.emeraldinsight.com/1750-6204.htm.

United Nations Conference on Trade and Development 2005. "Improving The Competitiveness of SMEs through Enhancing Productive Capacity.” Proceedings of Four Expert Meetings. United Nations, New York and Geneva.

Widyaningrum, N. 2003. Pola-pola eksploitasi Terhadap Usaha Kecil. Yayasan Akatiga, Bandung.

Wie, T.K. 2006. Policies for Private Sector Development In Indonesia. Asian Development Bank Paper Number 46, March, http://www.adbi.org/files/2006.03.d46.private.sector.dev.ind.pdf 